\title{
SZANSE I ZAGROŻENIA INWESTYCJI NA WYBRANYCH SEGMENTACH RYNKU FINANSOWEGO
}

\author{
Anna Wojtasińska \\ Koło Naukowe Inżynierii Finansowej \\ przy Katedrze Bankowości i Rynków Finansowych \\ Uniwersytetu Ekonomicznego w Katowicach
}

\section{Streszczenie}

Inwestycje finansowe są ważnym elementem finansów gospodarstw domowych. Dają szansę na zapewnienie im dobrobytu finansowego i poczucia bezpieczeństwa. Niosą jednak za sobą pewne zagrożenia. Inwestowanie to proces, podczas którego inwestor konstruuje portfel aktywów finansowych, odzwierciedlający określone cele inwestycyjne, np. maksymalizację zysku i/lub minimalizację ryzyka. Założeniem inwestycji jest zysk. Jednak nie zawsze inwestorom udaje się odnieść pożądany wynik często przez źle podejmowane decyzje inwestycyjne. Każdy z inwestorów ma świadomość, że im większa oczekiwana stopa zwrotu tym wyższe akceptowalne ryzyko inwestycyjne.

Celem artykułu jest pokazanie rentowności wybranych form inwestycji w instrumenty ryzykowne oraz przeprowadzenie analizy dochodowości inwestycji $w$ te walory z uwzględnieniem poziomu ryzyka na wybranych segmentach rynku finansowego - kapitałowym, metali szlachetnych i na rynku forex.

Słowa kluczowe: inwestycje, rynek kapitałowy, rynek metali szlachetnych, forex.

JEL Class: E44, G10. 


\section{WPROWADZENIE}

Rynek finansowy spełnia wiele funkcji. Jego poszczególne segmenty umożliwiają: zarządzanie płynnością, którą wspomagają instrumenty rynku pieniężnego; pozyskiwanie kapitału na inwestycje, alokację kapitału oraz jego wycenę, możliwe na rynku kapitałowym; a także efektywniejsze zarządzanie ryzykiem, dzięki instrumentom pochodnym. Rynek ten spełnia także wiele innych funkcji ważnych w gospodarce takich jak: porównanie krajowych cen towarów i usług z cenami za granicą, połączenie krajowego rynku finansowego z rynkiem międzynarodowym, co sprzyja rozwojowi handlu zagranicznego poszczególnych krajów.

Jedną z ważnych funkcji, wykorzystywanych przez indywidualnych konsumentów finansowych jest umożliwienie alokacji zgromadzonego kapitału. Indywidualni konsumenci finansowi, którzy dysponują nadwyżką pieniężną poszukują najbardziej optymalnych możliwości ulokowania tych środków. Rynek finansowy oferuje szeroki zakres możliwości: począwszy od instrumentów bezpiecznych, ale niestety przynoszących niezbyt wysoki dochód, takich jak lokaty bankowe czy obligacje skarbowe, idąc przez te ze średnim poziomem ryzyka, takich jak produkty strukturyzowane z gwarancją zwrotu kapitału - narażające na utratę dochodu, poprzez instrumenty narażające inwestorów zarówno na utratę dochodu i kapitału takie jak akcje czy tytuły uczestnictwa w funduszach, aż do skrajnie ryzykownych rozwiązań, np. instrumenty pochodne lub strategie wykorzystujące te instrumenty.

Inwestorzy, akceptujący ryzyko poszukują ofert w grupie instrumentów ryzykownych. Możliwości jest bardzo wiele i charakteryzują się one różnym poziomem ryzyka. Wpływa na to wiele czynników, w tym specyfika danego waloru, jako instrumentu inwestycyjnego. Szeroka i wciąż poszerzająca się gama ofert oznacza duże zróżnicowanie w tej grupie instrumentów w zakresie zarówno ich dochodowości, jak i ryzyka. Zasadne jest zatem przeanalizowanie poszczególnych możliwości z uwzględnieniem ich zalet i wad (szans i zagrożeń).

Celem artykułu jest przedstawienie wybranych form inwestycji w instrumenty ryzykowne oraz przeprowadzenie analizy badawczej której tematem jest dochodowość inwestycji w te walory z uwzględnieniem poziomu ryzyka.

Realizacja celu służy weryfikacji hipotezy, zakładającej zróżnicowany zakres dochodowości oraz różny poziom ryzyka charakteryzujących wybrane walory inwestycyjne.

Prezentowane w literaturze klasyfikacje instrumentów finansowych, umożliwiają wyodrębnienie różnych grup walorów inwestycyjnych, ze względu na ich cechy charakterystyczne, istotne z perspektywy inwestowania. Ważnymi kryteriami podejmowania decyzji inwestycyjnych $\mathrm{w}$ zakresie wyboru instrumentu/waloru inwestycyjnego jest jego dochodowość oraz ryzyko. Dlatego też waż- 
ny jest podział instrumentów finansowych na instrumenty wolne od ryzyka (free risky instruments) i instrumenty ryzykowne (risky instruments). Wybrany do analizy zestaw walorów ryzykownych (akcje, waluty, metale szlachetne) uwzględnia dodatkowo podział walorów ryzykownych na walory finansowe i walory rzeczowe. Analiza wybranych walorów pod względem ich cech pozwala na wyodrębnienie ich zalet i wad, jako walorów inwestycyjnych.

Charakterystyka cech wybranych grup instrumentów ryzykownych (akcji spółek giełdowych, metali szlachetnych oraz walut) zostanie dokonana w oparciu o literaturę przedmiotu, tj. recenzowane monografie i artykuły naukowe. W badaniach empirycznych polegających na wyliczeniu dochodowości i ryzyka wykorzystane zostaną dane dotyczące notowań wybranych walorów za lata 2000-2017 dostępne na witrynie internetowej stooq.pl. Dla wyliczenia poziomu dochodowości wykorzystana zostanie roczna stopa zwrotu, natomiast dla kreślenia poziomu ryzyka odchylenie standardowe (wyliczone dla okresów rocznych.

\section{INSTRUMENTY I CECHY RYNKU KAPITAŁOWEGO, RYNKU METALI SZLACHETNYCH ORAZ FOREX'U}

\subsection{Rynek kapitałowy}

Rynek kapitałowy, obok rynku pieniężnego, stanowi podstawowy segment rynku finansowego. Rynek kapitałowy jest to rynek kapitałów średnio- i długoterminowych przeznaczonych na finansowanie inwestycji. Ważną instytucją ułatwiająca przeprowadzanie operacji na rynku kapitałowym jest giełda papierów wartościowych. W Polsce pierwsza giełda papierów wartościowych została uruchomiona 12 maja 1817 roku. W XIX w. Przedmiotem handlu na giełdzie warszawskiej były przede wszystkim weksle i obligacje. Handel akcjami rozwiną się na szerszą skalę. Obecnie Giełda Papierów Wartościowych w Warszawie (GPW) jest największą giełdą regionu Europy Środkowo-Wschodniej i organizuje obrót na jednym z najdynamiczniej rozwijających się rynków kapitałowych w Europie [www1].

Rynek kapitałowy pośrednio umożliwia także innowacyjność gospodarki skutkującą wzrostem kapitału państwa, co z kolei prowadzi do zwiększenia konkurencyjności gospodarki wobec innych krajów, co w dalszej kolejności do zwiększenia elastyczności gospodarki w dostosowywaniu się do zmian [Kulpaka 2007].

Instrumenty finansowe funkcjonujące w ramach rynku kapitałowego są, co do zasady, papierami wartościowymi. Papier wartościowy jest to dokument, którego posiadanie obliguje do wykonywania praw wyrażonych w treści tego dokumentu. Spośród najbardziej znanych papierów wartościowych rynku kapita- 
łowego, których szczegółowe omówienie przedstawiono w dalszej części artykułu, wymienić należy [Jajuga i Jajuga 2011]:

- Akcje - są to dokumenty świadczące o udziale jego właściciela w kapitale spółki akcyjnej, która jest formą prowadzenia działalności gospodarczej. Podstawowymi parametrami charakteryzującymi akcje są : wartość nominalna, cena emisyjna, nadwyżka ceny emisyjnej nad wartością nominalną, cena rynkowa,

- Obligacje - są to papiery wartościowe zaliczane do instrumentów dłużnych. Emitent stwierdza w obligacji, że jest dłużnikiem właściciela obligacji i zobowiązuje się wobec niego do spełnienia określonego świadczenia. Świadczenie może mieć charakter pieniężny, niepieniężny lub też mieszany. Podstawowymi parametrami charakteryzującymi obligacje są: wartość nominalna, cena emisyjna, cena rynkowa, termin wykupu, oprocentowanie, termin płatności odsetek, Ze względu na termin wykupu, występują obligacje krótkoterminowe, średnioterminowe i długoterminowe. Ze względu na sposób oprocentowania, wyróżnia się obligacje: o oprocentowaniu stałym, o oprocentowaniu zmiennym.

- Kwity depozytowe - są papierami wartościowymi emitowanymi niejako „W zastępstwie” właściwego papieru wartościowego, jakim są akcje. Kwity depozytowe emitowane są $\mathrm{w}$ oparciu o akcje spółki mającej siedzibę w innym państwie niż państwo, w którym następuje emisja kwitów. Atrakcyjność kwitów depozytowych wynika $\mathrm{z}$ dwóch ważnych czynników. Po pierwsze, z punktu widzenia emitenta akcji, kwity depozytowe dają mu możliwość zaistnienia na rynkach zagranicznych. Po drugie, z punktu widzenia inwestorów, kwity depozytowe umożliwiają „,nabywanie” akcji spółek zagranicznych.

- Listy zastawne - są dłużnymi papierami wartościowymi, w których emitent zobowiązuje się do zwrotu nabywcy listu kwoty głównej wraz z odsetkami. Listy zastawne charakteryzują się wysokim poziomem bezpieczeństwa w wyniku wielu ograniczeń ustawowych odnośnie samego papieru jak i działalności banku hipotecznego.

- Certyfikaty inwestycyjne - są instrumentami finansowymi emitowanymi przez fundusze inwestycyjne zamknięte i stanowią swego rodzaju udział w funduszu inwestycyjnym.

- Prawa poboru - są bardzo ściśle związane z akcjami konkretnej emisji, istnieją przez bardzo krótki czas w porównaniu z tymi akcjami. W przypadku prawa poboru, jakkolwiek będącego papierem wartościowym, trudno mówić o emitencie, ponieważ instrumenty te powstają „,automatycznie” w związku z nową emisją akcji spółki i wyłącznie akcjonariusz może zdecydować o ich zbyciu. Wartość praw poboru zależy bezpośrednio od ceny akcji.

- Prawa do akcji - są uznawane niemalże jako instrument tożsamy z akcją. Dla ważności emisji akcji wymagane jest jej zarejestrowanie przez sąd rejestrowy. 
- Jednostki uczestnictwa - są zbywane przez fundusze inwestycyjne otwarte i specjalistyczne fundusze inwestycyjne otwarte, stanowią tytuł prawny uczestników funduszy do udziału w wartości aktywów netto funduszu.

Analizując ceny walorów notowanych na giełdzie kapitałowej, można stwierdzić, iż inwestowanie na rynku kapitałowym może prowadzić do dużych zysków. $Z$ drugiej jednak strony inwestycje na rynku kapitałowym często narażają inwestorów na duże straty. Są one zwykle tym większe, im mniejszy poziom wiedzy finansowej charakteryzuje inwestorów [Frączek 2012: 85-90].

\subsection{Rynek metali szlachetnych}

Drugim z analizowanych rynków umożliwiających alokację kapitału (inwestycje) jest rynek metali szlachetnych. Od niepamiętnych czasów człowiek wykorzystywał dobra naturalne w handlu wymiennym. Na przestrzeni wieków metale szlachetne zyskiwały na wartości i często łączyło się je z pojęciem władzy i dobrobytu (zwłaszcza złoto). Początkowo wykorzystywano je do produkcji monet i wyrobów jubilerskich, jednak z czasem wzrastało również zainteresowanie metalami, jako sposobem alokacji kapitału stanowiącym zabezpieczenie zwłaszcza w okresie destabilizacji i kryzysu na rynkach krajowych i międzynarodowych. Niektóre metale szlachetne (np. złoto) od wieków wykorzystywane były także w jubilerstwie, medycynie, przemyśle, a nawet w kuchni. Poza złotem do grupy matali szlachetnych wykorzystywanych $\mathrm{w}$ inwestycjach należą także srebro i platyna.

Charakteryzując metale szlachetne, jako walory inwestycyjne, należy zwrócić uwagę na takich cechy, jak: niezniszczalność, płynność, niezależność od innych walorów (zwłaszcza finansowych), ponadnarodowość, ograniczoność zasobów odporność na dekoniunkturę i ponadczasowość, odporność na zmiany na rynkach giełdowych. Jedną z ważnych funkcji metali szlachetnych jest także to, że są one przedmiotem rezerw banków centralnych [Borowski 2008: 179-193].

Do głównych wad metali szlachetnych, jako przedmiotu inwestycji należą: koszty przechowywania np. w sejfach, oraz kradzież.

Inwestycje w złoto może przybierać różne formy. Poza zakupem złota w formie materialnej, czyli sztabek, monet i biżuterii, istnieją także możliwości inwestowania $\mathrm{w}$ akcje branży zajmującej się wydobyciem oraz obróbką złota. Niska korelacja złota $\mathrm{z}$ tradycyjnymi aktywami finansowymi przyczynia się do eliminacji ryzyka. Złoto traktowane jest jako waluta globalna. Według analityków rynku kapitałowego powinno stanowić fundament wszelkich inwestycji, ponieważ lokata $\mathrm{w}$ złoto praktycznie jest pozbawiona ryzyka i uznaje się ją za ponadczasową i najbezpieczniejszą na świecie. Cena złota $w$ głównej mierze uzależniona jest od popytu i podaży na rynku. Złoto często sprawdza się jako 
walor inwestycyjny w okresach bessy na rynkach kapitałowych. Złoto jest odwrotnie skorelowane $\mathrm{z}$ rynkiem akcji i zazwyczaj jest idealną alternatywą w czasie dekoniunktury i w okresach konfliktów.

Poza wykorzystywaniem złota jako waloru inwestycyjnego, złoto można również kolekcjonować, gdyż posiada ono również walory estetyczne. Dzisiejszy rynek pozwala wybrać formę inwestowania w złoto. Inwestować można na wiele sposobów, dlatego podjęcie decyzji o nabyciu złota jest dopiero pierwszym krokiem indywidualnego inwestora na drodze do faktycznej dywersyfikacji portfela, uwzględniającej złoty kruszec.

Inwestycje w złoto nie są jednak pozbawione wad. Złote sztabki - jako forma inwestycji - postrzegane są jako mało płynny walor. Inwestycjom w złoto często towarzyszy ryzyko walutowe, ponieważ ceny złota najczęściej notowane są w USD, natomiast walutą rozliczeniową jest waluta kraju, w którym rozlicza się inwestor. Kolejnym zagrożeniem przy bezpośrednim inwestowaniu w złoto jest spread, czyli różnica między ceną nabycia i sprzedaży, co na starcie obniża wartość naszej ,złotej” lokaty. Poza tym zakup sztabek złota wiąże się zazwyczaj z inwestowaniem znacznych kwot [Frączek 2012: 85-90]. Inwestycja w złoto to głównie inwestycje długoterminowe. Na rynku istnieje wiele możliwości inwestycji w złoto:

1. Złoto w formie fizycznej - wymaga dużych nakładów kapitału oraz uwzględnienia kosztów przechowania;

2. Złote monety - w ostatnich latach świadomość inwestorów znacznie wzrosła i zainteresowali się oni monetami kolekcjonerskim, które produkowane są przez Mennicę Polską na zlecenie Narodowego Banku Polskiego w celach tezauryzacyjnych i inwestycyjnych;

3. Biżuteria, która nigdy nie traci na wartości, jest zazwyczaj przekazywana jako dziedzictwo rodzinne $\mathrm{z}$ pokolenia na pokolenie;

4. Jednostki funduszy inwestujących w złoto - na polskim rynku kapitałowym dostępnych jest kilka certyfikatów inwestycyjnych funduszy, które lokują dużą część swoich aktywów w złoto i inne metale szlachetne, jak również w akcje kopalń złota lub firm jubilerskich;

5. Akcje spółek wydobywających złoto - na polskim rynku kapitałowym występują ograniczone możliwości inwestowania w tego typu spółki;

6. Kontrakty terminowe na złoto;

7. Produkty strukturyzowane oparte na złocie;

8. Certyfikaty surowcowe (oparte na złotym kruszcu) notowane na GPW - produkty te oferują największe banki inwestycyjne.

Srebro jest mniej popularną formą inwestycji, chociaż to srebro najprawdopodobniej było surowcem, z którego wytwarzano pierwsze monety. Do najważniejszych zalet srebra jako formy inwestycji można zaliczyć: niezwykłą rzadkość, wielkość jego rezerw, korzystna sytuacja fundamentalna, czyli stabilna 
produkcja. Srebro pozostaje relatywnie tanie w porównaniu do innych klas aktywów. Dużym plusem inwestycji w srebro jest to, że zabezpiecza ono przed inflacją, hiperinflacją a także deflacją [Sieroń 2014]. Dzięki temu, iż srebro jest bardzo słabo skorelowane $z$ aktywami finansowymi jest dobrym sposobem dywersyfikacji portfela inwestycyjnego. Ponadto srebro jest substytutem złota, a jednocześnie jest osiągalne dla każdego i nierzadko można osiągnąć wyższe stopy zwrotu niż na złocie.

Podobnie jak w przypadku złota, wachlarz możliwych instrumentów inwestycyjnych jest szeroki:

1. Inwestowanie w srebro w postaci fizycznej na przykład sztabek inwestycyjnych;

2. Zakup srebrnych monet - na polskim rynku kolekcjonerskim srebrne monety są popularniejsze niż monety złote, ponieważ są tańsze i bardziej płynne;

3. Pośrednie inwestowanie w akcje spółek zajmujących się produkcją srebra - w Polsce mogą to być inwestycje w spółkę KGHM SA;

4. Zakup certyfikatów strukturyzowanych;

5. Jednostki funduszy inwestycyjnych - poprzez zakup instrumentów, które są powiązane z kursami metali szlachetnych (w tym srebra);

6. Medale;

7. Worki granulatu srebrnego z przeznaczeniem na przykład dla jubilerów;

8. Instrumenty pochodne oparte na srebrze, takie jak kontrakty terminowe i opcje, którymi handel odbywa się na giełdach na całym świecie.

Inwestowanie w srebrne sztabki oraz monety to opłacalna $\mathrm{i}$ bezpieczna forma zabezpieczania majątku, a także dobra metoda dywersyfikacji portfela inwestycyjnego. W przypadku inwestycji w srebro warto jednak prześledzić historyczne notowania oraz aktualne przewidywania specjalistów, szczególnie w przypadku, kiedy liczy się na szybki zysk.

Platyna jako walor inwestycyjny jest także warta rozważenia przede wszystkim dlatego, że: jest piętnastokrotnie rzadszym metalem od złota, a jej cena jest bardzo zbliżona do złota. Obecnie produkuje się 5\% mniej platyny niż się zużywa. Wraz z zamykaniem kopalni deficyt będzie się powiększał. Platyna początkowo wykorzystywana była przede wszystkim w jubilerstwie, w medycynie w przemyśle elektronicznym i chemicznym, ale najszerzej w przemyśle motoryzacyjnym, gdzie była wykorzystywana jako katalizator. Nie cieszy się jednak popularnością jako walor inwestycyjny, ponieważ jest to towar nietypowy, o dość niskiej płynności i od kilku lat znajduje się w trendzie spadkowym.

Popularnymi formami inwestycji w platynę są monety, na których zakup mogą sobie pozwolić z inwestorzy z mniejszym kapitałem. Alternatywą dla kupna sztabek lub monet są fundusze typu ETF, których jednostki uczestnictwa czynią z inwestora posiadacza określonej ilości kruszcu, a inwestor nie ponosi kosztów przechowywania i ubezpieczenia metal [Frączek 2012: 85-90]. 


\subsection{Rynek walutowy (forex)}

Kolejnym rynkiem analizowanym pod względem możliwości inwestowania jest forex, stanowiący największy segment rynku finansowego. Jego popularność $\mathrm{z}$ roku na rok staje się coraz większa a dostępność szersza. Jest on rynkiem wymiany walut, nie ma on fizycznej lokalizacji, a zdecydowana większość działań opiera się na sieciach elektronicznych i telefonicznych pomiędzy bankami, przedsiębiorstwami i klientami indywidualnymi.

Forex w swojej obecnej formie istnieje od 1971 roku, kiedy to prezydent Nixon zdecydował się zawiesić wymienialność dolara na złoto. Waluty zaczęły swobodnie przepływać pomiędzy krajami. Lata 70. to okres ustalania się płynności, szybkości i cen na rynku walutowym. Lata 80. to z kolei rozwój komputerów i technologii, który przyspieszył i ułatwił przepływ walut pomiędzy największymi gospodarkami świata, niezależnie od położenia i stref czasowych [www3].

O rynku wymiany walut mówi się ze ma on wirtualną naturę i że charakteryzowany jest przez niematerialność towaru, dematerializację procesów transakcyjnych i wysoki poziom technologiczny. Czynniki te wpływają na kształt forexu, ale przede wszystkim przyczyniają się do systematycznego wzrostu jego obrotów, który na dzień dzisiejszy może wynosić nawet 5 mld USD dolarów dziennego obrotu.

Inwestowanie $\mathrm{w}$ waluty jak każdy proces także ma swoje plusy i minusy. Inwestorom dysponującym odpowiednią wiedzą i umiejętnościami oraz kierującym się zdrowym rozsądkiem oraz wiedzą na temat rynku potrafi przynieść bardzo duże profity. $Z$ drugiej jednak strony inwestycje na rynku walutowym mogą okazać się źródłem ogromnych strat.

Nie tak dawno rynek walutowy był zarezerwowany głównie dla banków i największych inwestorów instytucjonalnych. Rozwój Internetu, a co za tym idzie miejsc obrotu online sprawił, że współcześnie rynek forex jest dostępny dla każdego inwestora indywidualnego, niezależnie od możliwości portfela [Herbert 2014].

Kolejną ważną zaletą tego rynku jest to, że ma on wyjątkowo dużą płynność, która w wielu przypadkach zmniejsza skuteczność prób wpływania na kursy walut, nawet te podejmowane przez banki centralne największych światowych gospodarek, które w długim terminie nie są w stanie zmienić rynkowego trendu.

Istnieją także liczne wady systemów opierających się na inwestowaniu w walutę. Należą do nich między innymi duże ryzyko strat w przypadku nagłego spadku wartości waluty, ryzyko wchłonięcia przez inflację całego wypracowanego zysku z inwestycji w daną walutę, popadnięcie w pułapkę zadłużenia, które może wyniknąć za pośrednictwem wzrostu wartości kredytu w walucie. Przykładem mogą być kredytobiorcy zadłużeni we frankach szwajcarskich, którego wartość od 2011 roku nieustannie rośnie. 


\section{ANALIZA EFEKTYWNOŚCI I RYZYKA INWESTYCI DOKONYWANYCH NA RYNKU KAPITAŁOWYM, METALI SZLACHETNYCH I NA RYNKU FOREX}

\subsection{Efektywność, ryzyko i płynność wybranych rynków}

Każdy inwestor w zależności od jego podejścia do rzeczy materialnych wyraża pewne oczekiwania co do efektywności inwestycji, zaś jego stosunek do ryzyka wpływa na preferencje w zakresie bezpieczeństwa dokonywanych lokat. W przeprowadzonej analizie skupiono się przede wszystkim na efektywności i ryzyku jako kryteriach wyboru inwestycji oraz dodatkowo zwrócono uwagę na płynność, która wpływa na bezpieczeństwo lokowanych środków finansowych.

$\mathrm{Na}$ rynku kapitałowym istnieje wiele możliwości inwestowania, charakteryzujących się zróżnicowanym poziomem efektywności oraz ryzyka. Także płynność instrumentów charakterystycznych dla tego segmentu jest bardzo zróżnicowana i zależy od instrumentu oraz sytuacji na rynku. Długoterminowe instrumenty dłużne o stałej stopie procentowej zazwyczaj charakteryzuje relatywnie niski dochód i ryzyko oraz niska płynność z powodu braku zorganizowanego obrotu. Jednak już biorąc pod uwagę akcje spółki giełdowej, którą może charakteryzować duża płynność - istnieje możliwość (ale nie gwarancja) osiągnięcia dużego zysku pod warunkiem podjęcia wysokiego ryzyka. Efektywne inwestycje w akcje są możliwe zarówno w krótkim, jak i długim okresie inwestowania.

Efektywność inwestycji na rynku metali szlachetnych, szczególnie na rynku złota i srebra jest także zróżnicowana. Złoto jest uważane za jeden z najkorzystniejszych po względem efektywności walorów inwestycyjnych, zyskujących na wartości w czasach chaosu gospodarczego czy politycznego. Jednakże metale szlachetne postrzegane sa głównie jako inwestycja długoterminowa a ryzyko w te walory jest uważane za relatywnie niskie, chociaż walory te należą do grupy walorów ryzykownych, wrażliwych na wpływ wielu czynników, w tym ekonomicznych i politycznych. Ponieważ cena złota wpływa na wartość pozostałych metali szlachetnych, to zmiany na tym rynku odgrywają ważną rolę w całym segmencie metali szlachetnych. Płynność na giełdzie metali szlachetnych jest wysoka jeśli uwzględni się wszystkie możliwe formy inwestycji. Należy jednak mieć na uwadze, że w ramach poszczególnych instrumentów płynność może być zróżnicowana, np. im niższa waga sztabki tym łatwiejsza jest jej sprzedaż - a tym samym wyższa płynność. Innym przykładem wyższej efektywności są certyfikaty zwiększające płynność inwestycji, ponieważ umożliwiają łatwiejszą (szybszą) sprzedaż posiadanego złota lub srebra.

Poziom możliwych do osiągnięcia zysków z instrumentów rynku walutowego wydaje się być najwyższy, głównie z uwagi na częste inwestycje w waluty z wykorzystaniem instrumentów pochodnych. Ostatnie z wymienionych należą 
jednak do instrumentów o najwyższym stopniu ryzyka, co oznacza możliwość poniesienia dotkliwych strat na rynku walutowym. Rynek walutowy jest rynkiem bardzo płynnym. Wpływa na to wiele czynników. Rynek walutowy działa w formule follow the sun, na wielu parach walutowych i z ogromnymi obrotami, transakcjami, które nie wiążą się z kosztami [Wiśniewski 2008]. Wysokiej płynności rynku walutowego sprzyjają także wciąż zwiększające się obroty na forex-ie, współpraca z czołowymi dostawcami walut, którymi są główne banki, licencjonowane firmy inwestycyjne i brokerzy. Wysoka płynność rynku forex zapewnia szybką i bezpieczną realizację zleceń, nawet jeśli ich wolumen jest bardzo duży.

Analizowane rynki (kapitałowy, metali szlachetnych oraz walutowy) charakteryzują się różną dynamiką, zakresem zmian wahań, długości trendów oraz zmiennością. Warto zatem dokonać dokładniejszej analizy skuteczności inwestowania na tych rynkach. Wyniki przeprowadzonych badań opierają się na obliczeniach efektywności, która mierzona jest za pomocą rocznej stopy zwrotu, natomiast ryzyko mierzone jest odchyleniem standardowym (czyli zmiennością cen walorów), policzonym również przedziałów rocznych.

W dalszej części przedstawiona została analiza efektywności wykresów oraz ryzyka inwestycji. Efektywność mierzona za pomocą rocznej stopy zwrotu, ryzyko natomiast wyrażone jest na podstawie odchylenia standardowego (czyli zmiennością cen walorów). Analiza dotyczy lat 2000-2017.

\subsection{Analiza wykresów stopy zwrotu i ryzyka inwestycji na rynku instrumentów finansowych}

Badaniom efektywności i ryzyka inwestycji poddano akcje Microsoftu, które według artykułu FORBES.PL pod koniec roku 201 osiągnęły rekordowe notowania, oraz indeksów szerokiego rynku akcji: WIG20 oraz S\&P500 [www2, dostęp: 21.10.2016].

Akcje Microsoftu od zawsze notowane są bardzo wysoko, co sprzyja inwestycjom w ten walor. Można zauważyć, że w ostatnich latach roczna stopa zwrotu wykazuje tendencję malejącą. Przyczyną tej sytuacji jest najprawdopodobniej wprowadzenie przez firmę bardzo nowatorskich technologii do swoich produktów, które z powodu swojej ceny dostępne są głownie dla ludzi o zasobnych portfelach.

WIG20 to indeks, w skład którego wchodzą głównie banki, spółki surowcowe (PGNiG i PKN Orlen) oraz ubezpieczeniowe (PZU) notowane na Giełdzie Papierów Wartościowych w Warszawie. Można zauważyć, że inwestycja ta jest dochodowa, jednak ryzyko jest widoczne, zwłaszcza w czasie kryzysu w 2008 roku. 


\section{Roczna stopa zwrotu}

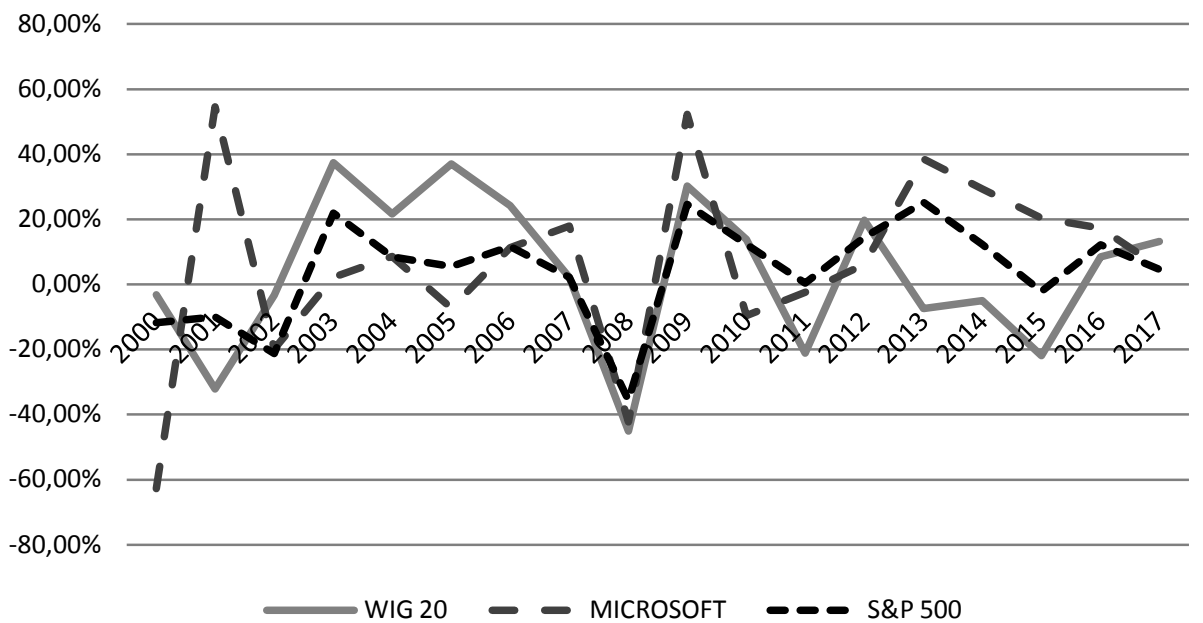

Wykres 1. Roczna stopa zwrotu inwestycji w wybrane akcje i indeksy oparte na akcjach w latach 2000-2017

Źródło: dane historyczne [www4]

\section{Roczne ryzyko}

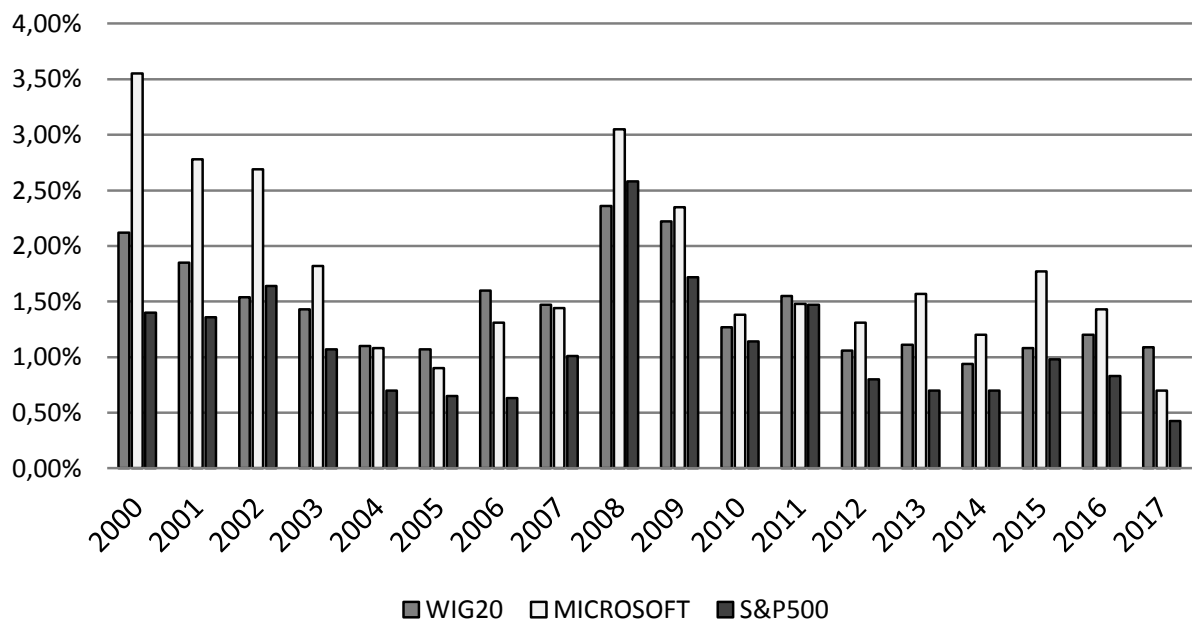

Wykres 2. Ryzyko inwestycji w wybrane akcje na przełomie lat 2000-2017

Źródło: dane historyczne [www4]. 
S\&P 500 to indeks, w skład, którego wchodzi 500 przedsiębiorstw o największej kapitalizacji, notowanych na New York Stock Exchange i NASDAQ. $\mathrm{W}$ analizowanym okresie inwestycje $\mathrm{w}$ indeks przynosiły inwestorom zarówno zyski jak i straty.

Wszystkim analizowanym walorom rynku kapitałowego towarzyszy jedno główne załamanie w latach 2008-2009 z powodu kryzysu. Ryzyko w tym czasie jest największe z powodu ograniczonej przewidywalności wydarzeń i możliwych spadków lub skoków kursów.

Analizując ryzyko mierzone zmiennością można stwierdzić, że najmniejsza zmienność w każdym badanym okresie obserwowana jest na indeksie S\&P.

\subsection{Analiza wykresów stopy zwrotu i ryzyka inwestycji w metale szlachetne}

Analizowanymi metalami szlachetnymi będą kolejno: złoto, srebro, platyna.

Wartości rocznych stóp zwrotu możliwych do osiągnięcia w okresach rocznych z inwestycji w metale szlachetne wskazują na atrakcyjność tych inwestycji. Szczególnie atrakcyjny pod względem inwestycyjnym jest rynek złota, który umożliwia osiągnięcie dodatniej stopy zwrotu nawet w czasie kryzysu. Sytuacja na tym rynku uległa zmianie (ujemne stopy zwrotu) jedynie w latach 20132014. Można zatem stwierdzić, że inwestując w złoto są inwestycjami bezpiecznymi, co dodatkowo potwierdzają dane zawarte na wykresie 4, przedstawiające poziom ryzyka inwestycji w poszczególne metale szlachetne. Złoto na tle pozostałych walorów w tej grupie prezentuje się korzystniej.

\section{Roczna stopa zwrotu}

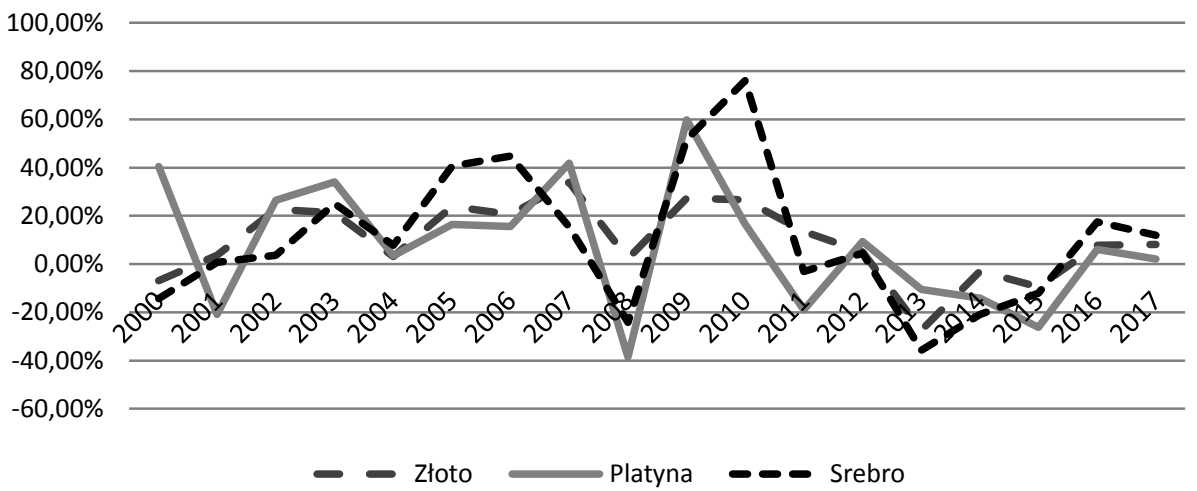

Wykres 3. Roczna stopa zwrotu inwestycji w wybrane metale szlachetne w latach 2000-2017

Źródło: dane historyczne [www4]. 


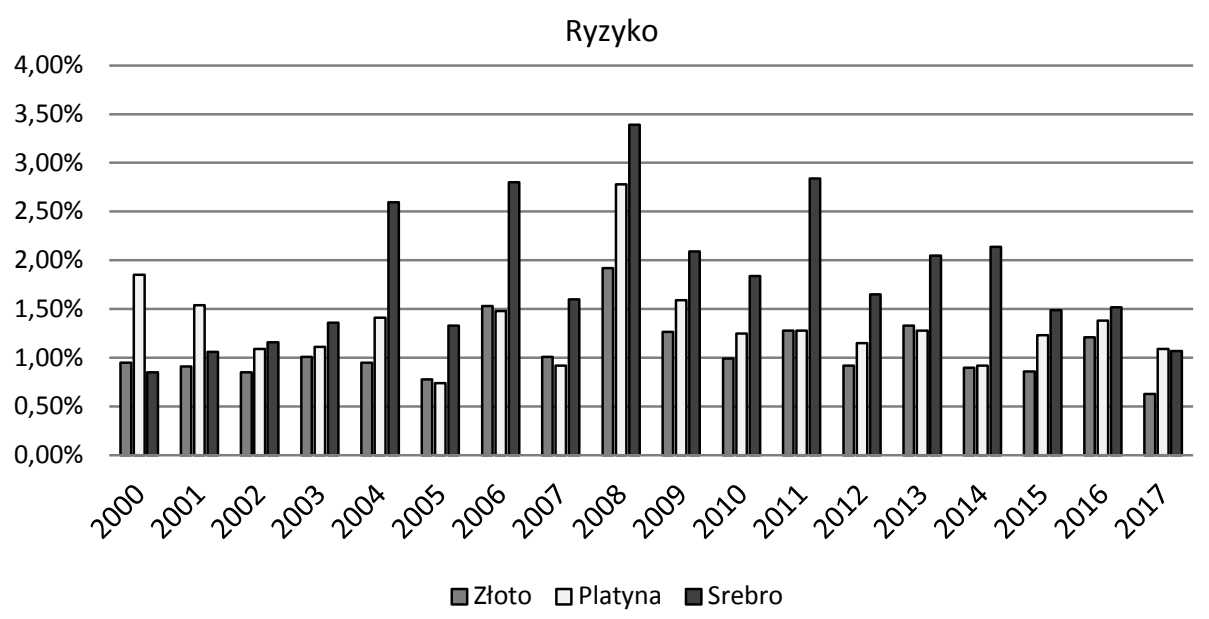

Wykres 4. Ryzyko inwestycji w wybrane metale szlachetne na przełomie lat 2000-2017

Źródło: dane historyczne [www4].

Poziom stopy zwrotu $\mathrm{z}$ inwestycji w srebro $\mathrm{w}$ analizowanym okresie także może być uznany za zadowalający. W wielu okresach efektywność inwestycji w srebro jest nawet wyższa niż inwestycji w złoto. Częściej jednak niż w przypadku złota inwestycje w srebro dają przynoszą inwestorom straty. Oznacza to większą zmienność na rynku srebra, co potwierdzają dane przedstawiające poziom ryzyka.

Przykład platyny także wskazuje na okresy dodatniej i okresy ujemnej rocznej stopy zwrotu i towarzyszące tym zmianom zmiany poziomu ryzyka.

$\mathrm{Na}$ wykresach 3 i 4 widać, że największym ryzykiem obciążone jest srebro natomiast ma ono największą stopę zwrotu.

Należy jednak pamiętać, że w inwestycjach długoterminowych w metale szlachetne (i inne walory rzeczowe typowe dla inwestycji długoterminowych) ważna jest aktualna i poprzedzająca ją sytuacja na rynku danego waloru, świadcząca o tym, czy dany walor jest niedowartościowany, czy też ceny są już mocno wygórowane. Należy analizować dotychczasowe trendy oraz próbować zidentyfikować obecny etap koniunktury na danym walorze.

\subsection{Analiza wykresów stopy zwrotu i ryzyka inwestycji w waluty}

Zastanawiając się nad zasadnością inwestycji w waluty, przeprowadzona została analiza stopy zwrotu i ryzyka inwestycji w wybrane kursy walut. Badaniom poddano następujące kursy walut: EUR/PLN, EUR/USD oraz GBP/USD. 


\section{Roczna stopa zwrotu}

$30,00 \%$

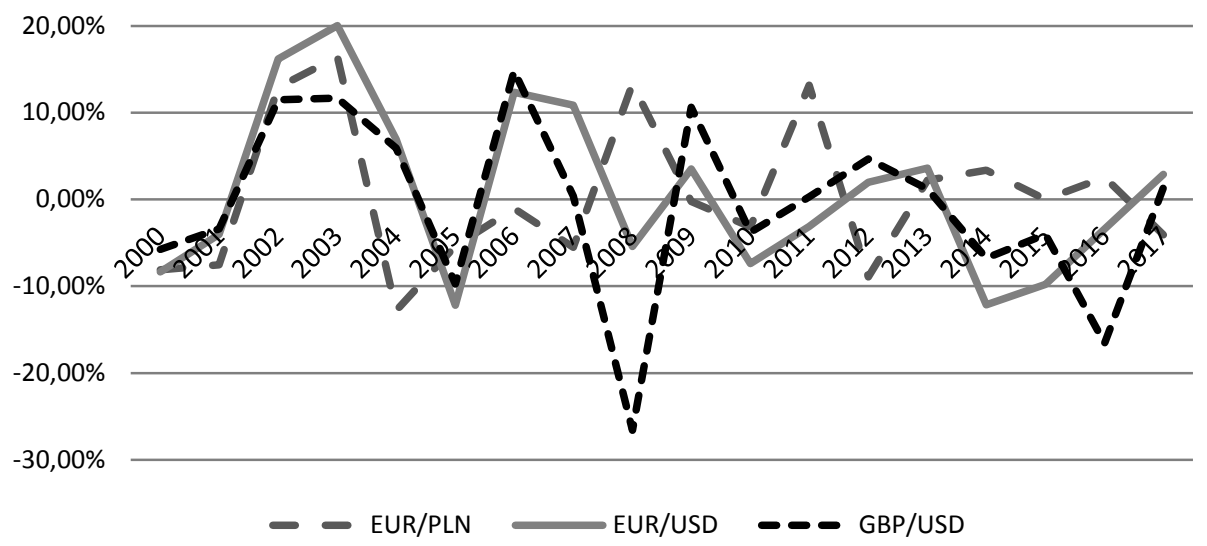

Wykres 5. Roczna stopa zwrotu inwestycji w wybrane waluty w okresie 2000-2017 Źródło: dane historyczne [www4].

\section{Ryzyko}

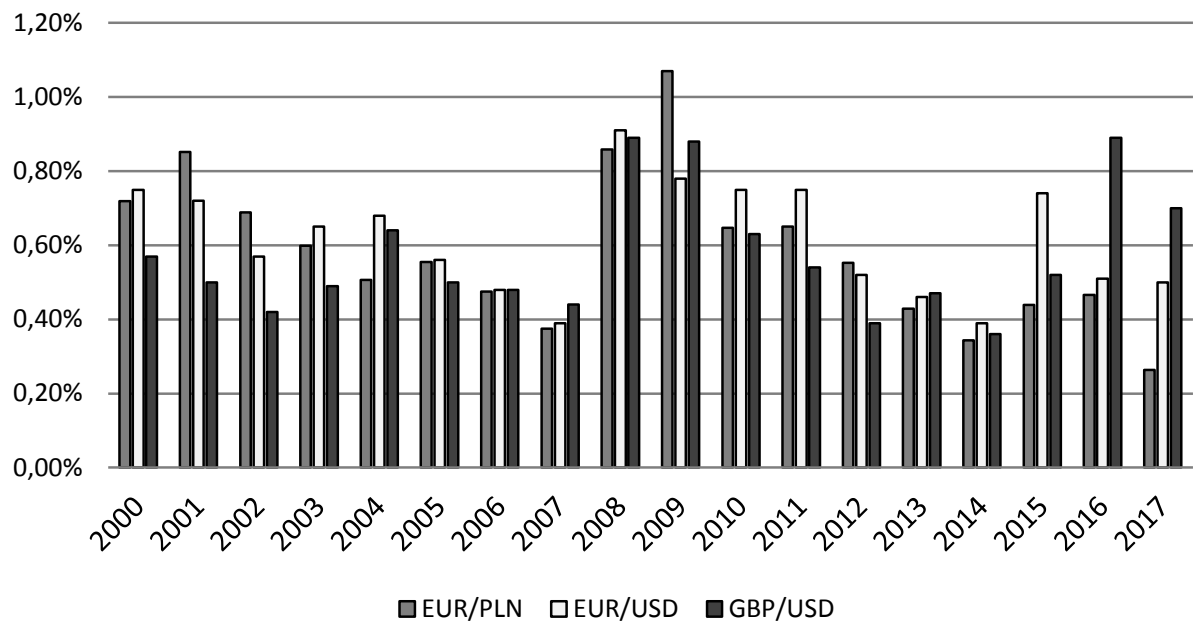

Wykres 6. Ryzyko inwestycji w wybrane waluty na przełomie lat 2000-2017

Źródło: dane historyczne [www4]. 
Dane zaprezentowane na wykresie 5 i 6 potwierdzają zróżnicowanie, zarówno w wartościach stóp zwrotu, jak i w poziomach ryzyka analizowanych par walutowych. Można zauważyć zróżnicowane poziomy stóp zwrotu, mieszczące się jednak w mniejszym przedziale wahań, niż stopy zwrotu instrumentów rynku kapitałowego i walorów umożliwiających inwestycje w metale szlachetne. Wyznaczone poziomy ryzyka dla poszczególnych okresów rocznych także mieszczą się na niższym poziomie, jednak relacje pomiędzy ich poziomami dla wybranych walorów zmieniają się dużo częściej, niż w przypadku akcji, indeksów i metali szlachetnych.

Para GBP/USD jest bardzo mało stabilną parą walut, charakteryzująca się dużą amplitudą zmienności kursu: od wysokich notowań w latach 2002, 2006 czy 2009 do bardzo niskich w latach 2008, 2016. W porównaniu do innych analizowanych par walutowych stopy zwrotu uzyskane z pary walutowej GBP/USD w okresie kryzysu w 2008-2009 kształtowały się na relatywnie niższym poziomie. Największa zmienność w czasie rozpoczęcia kryzysu charakteryzowała parę walutową EUR/PLN, która w tym samym czasie charakteryzowała się największą stopą zwrotu.

Analiza danych zawartych na wykresach 5 i 6 wskazuje, że inwestycje w waluty są bardzo niepewne. Należy przypomnieć, że zmiany kursów walut zależą od sytuacji w gospodarkach krajów tych walut. Inwestowanie w waluty wymaga posiadania określonej wiedzy finansowej oraz dostępu do bieżących informacji na temat sytuacji gospodarczej krajów interesujących inwestora walut.

Podsumowując przeprowadzone badania, można zauważyć, iż na każdym z rynków począwszy od rynku instrumentów a kończąc na rynku walutowym można zarówno osiągnąć zyski jak i ponieść straty. Zdecydowanie wykazujące największą dochodowość są inwestycje w metale szlachetne charakteryzują się one wysoką stopą zwrotu (przeciętnie na poziomie $40 \%$, z wynikami osiągającymi około $80 \%$ ). Najmniejszą opłacalnością charakteryzują się instrumenty rynku walut, jednocześnie inwestycje te obarczone są małym ryzykiem $(<1 \%)$. Na rynkach można zauważyć dużą amplitudę zmienności notowań. W latach 2009-2011 wykresy pokazują wysokie stopy zwrotu na wszystkich segmentach rynku, zaś rok 2008 charakteryzuje się dużym ryzykiem inwestycji i małą stopą zwrotu, co wynika głownie z ówczesnego kryzysu gospodarczego.

Umiejętność przeprowadzania stosownych analiz, znajomość sytuacji gospodarczej, interpretacja wyników i wykorzystywanie ich w procesie poodejmowania decyzji inwestycyjnych mogą okazać się bardzo opłacalne i przynosić oczekiwane wyniki finansowe, jednak każda inwestycja wiąże się z ryzykiem, od którego w dużej mierze zależy przyszły dochód inwestora. 


\title{
BIBLIOGRAFIA
}

Borowski K., 2008, Rynek złota i monet, [w:] I. Pruchnickia-Grabias (red.), Inwestycje alternatyw$n e, \mathrm{CeDeWu}$, Warszawa.

Frączek B., 2012, Inwestycje finansowe na rynkach polskim i zagranicznym, Wydawnictwo Uniwersytetu Ekonomicznego w Katowicach, Katowice.

Jajuga K., Jajuga T., 2011, Inwestycje. Instrumenty finansowe, aktywa niefinansowe, ryzyko finansowe, inżynieria finansowa, Wydawnictwo Naukowe PWN, Warszawa.

Kulpaka P. 2007, Giełdy w gospodarce, Polskie Wydawnictwo Ekonomiczne, Warszawa.

Mayo Herbert B., 2014, Inwestycje, Wydawnictwo Naukowe PWN, Warszawa.

Sieroń A., 2014, Inwestycje Alternatywne, Profit S.A. Warszawa, czerwiec.

Wiśniewski T., 2008, Ocena efektywności inwestycji rzeczowych ze szczególnym uwzględnieniem ryzyka, Wydawnictwo Naukowe Uniwersytetu Szczecińskiego, Szczecin.

[www1] witryna internetowa Giełdy Papierów Wartościowych w Warszawie: www.gpw.pl.

[www2] witryna internetowa www.forbes.pl.

[www3] witryna internetowa poradnik forex www.poradnik-forex.com.

[www4] witryna internetowa www.stooq.pl.

\section{CHANCES AND RISKS OF INVESTING IN SELECTED SEGMENTS OF THE FINANCIAL MARKET}

\begin{abstract}
Financial investments are an important part of household finances. They give an opportunity to ensure them financial prosperity and a sense of security. However, they carry some risks. Investing is the process by which an investor crate a portfolio of financial assets that reflects specific investment objectives, such as maximizing profit and / or minimizing risk. The investment is based on profit. However, investors do not always get the expected result often by badly made investment decisions. Each investor is aware that the higher the expected rate of return, the higher the acceptable investment risk. The main purpose of the article is to show the viability of selected forms of investment in risky instruments and to analyze the profitability of these investments taking into account the level of risk in selected financial market segments - capital, precious metals and the forex market.
\end{abstract}

Keywords: investments, capital market, precious metal market, forex. 